\title{
Association between a single nucleotide polymorphism in the bovine chemerin gene and carcass traits in Qinchuan cattle
}

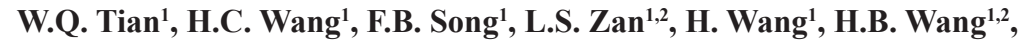 \\ Y.P. Xin ${ }^{1}$ and J.A. Ujan ${ }^{1}$ \\ ${ }^{1}$ College of Animal Science and Technology, Northwest A \& F University, \\ Yangling, Shaanxi, P.R. China \\ ${ }^{2}$ National Beef Cattle Improvement Centre, Yangling, Shaanxi, P.R. China \\ Corresponding author: L.S. Zan \\ E-mail: zanls@yahoo.com.cn
}

Genet. Mol. Res. 10 (4): 2833-2840 (2011)

Received January 3, 2011

Accepted April 6, 2011

Published November 17, 2011

DOI http://dx.doi.org/10.4238/2011.November.17.1

\begin{abstract}
Qinchuan is a red or yellow draft and beef breed in China. In order to identify a predictor of carcass traits on the basis of associations between carcass traits and gene polymorphism, variation in the bovine chemerin gene was investigated using PCR-single-strand conformational polymorphism and DNA sequencing. An SNP of A868G located in exon 2 of the Bos taurus chemerin gene was detected in 716 samples of six breeds (Jiaxian red, Luxi, Nan yang, Qinchuan, Simmental and Luxi crossbred steers, and Xia'nan), all in China, and three genotypes (AA, AG and GG) were found. Based on the $\chi^{2}$ test, the $\mathrm{AA} / \mathrm{AG} / \mathrm{GG}$ genotype frequencies of all six breeds were found to be in Hardy-Weinberg equilibrium. A possible association of A868G with some carcass traits was investigated in 106 Qinchuan cattle. Animals with the AG genotype were found to have significantly lower mean loin eye area and meat tenderness compared to those with the AA and GG genotypes. However, there was no significant association between any individual haplotype and backfat thickness, water holding capacity or
\end{abstract}


marbling score. We suggest that A868G could be used as a molecular marker in marker-assisted selection for carcass traits.

Key words: Bos taurus; Chemerin gene; PCR-SSCP; SNP; Carcass traits

\section{INTRODUCTION}

The chemerin gene, also known as the retinoic acid receptor responder 2 (RARRES2) and tazarotene-induced gene 2 (TIG2) (Nagpal et al., 1997), has been isolated as a novel chemoattractive agonistic protein binding to the G-protein-coupled receptor ChemR23 (Gantz et al., 1996; Owman et al., 1996; Samson et al., 1998; Meder et al., 2003), also considered to be the chemokine-like receptor-1 (CMKLR1) in 2003 (Wittamer et al., 2003; Zabel et al., 2005). Through its binding to chemerinR, chemerin is involved in regulating adipogenesis and adipocyte metabolism (Goralski et al., 2007), innate and adaptive immunity (Meder et al., 2003; Zabel et al., 2005; Wittamer et al., 2005), bone development (Methner et al., 1997), and immunodeficiency virus infections (Martensson et al., 2006). It potentiates insulin-stimulated glucose uptake and insulin signaling in 3T3-L1 adipocytes, which identifies chemerin as a novel adipokine (Takahashi et al., 2008). It was reported that the chemerin gene is expressed in many tissues, such as liver, lung, pituitary glands, ovaries, and kidney (Bozaoglu et al., 2007; Roh et al., 2007), but white adipose tissue was the only one with histiocytes that expressed high levels of chemerin and chemerinR (Meder et al., 2003; Goralski et al., 2007).

Recently, some investigators cloned chemerin and its receptor from the adipose tissues of Japanese Black cattle, and found that the DNA sequences and amino acid sequence of bovine chemerin and its receptor were highly homologous to those of humans, mice, and pigs (Song et al., 2010). Using the RT-PCR technology, they also found that bovine chemerin mRNA was highly expressed in adipose, kidney and liver tissues than in the other histiocytes detected, such as brain, heart, lung, and so on. Moreover, they found that the transcripts of chemerin and its receptor were up-regulated during adipocyte differentiation. Therefore, chemerin primarily acts on adipogenesis and adipocyte metabolism through its own receptor.

The chemerin gene of Bos taurus cattle is located on chromosome 4 (GenBank: NC_007302) and consists of six exons, with exons 2, 3, 4, and 5 coding a protein with 162 amino acids. However, there is no report about the SNPs of the chemerin gene in Bos taurus cattle.

In this study, we focused on the genetic variants of the chemerin gene to better understand its functional significance in Bos taurus cattle. We identified a variant form of the chemerin gene and analyzed the relationship between the SNP and some carcass traits, including loin-eye area (LEA), meat tenderness (TD), backfat thickness (BFT), water holding capacity (WHC), and marbling score (MS) in Qinchuan cattle of China.

\section{MATERIAL AND METHODS}

\section{Sample collection and DNA extraction}

All 716 blood samples were randomly selected from six cattle breeds as follows: Jiaxian red (JRC, $N=71$, Henan Province of China), Luxi (LX, N =69, Shandong Province 
of China), Nan yang (NY, N = 81, Henan Province of China), Qinchuan (QC, N = 366, Shanxi Province of China), Simmental and Luxi crossbred steers (SL, N = 53, Shandong Province of China), and Xia'nan (XN, N =76, Henan Province of China).

A total of 76 Qinchuan heifers, 1-1.5 years old, were randomly selected in the same farms under strictly standardized conditions, and data on five carcass traits, namely LEA, TD, BFT, WHC, and MS, were used in statistical analysis.

\section{DNA preparation}

The animals' blood samples were obtained, treated with $2 \%$ heparin and stored at $-80^{\circ} \mathrm{C}$. Genomic DNA was extracted from blood leukocytes by a standard phenol-chloroform protocol method (Mullenbach et al., 1989).

\section{PCR conditions}

According to the Bos taurus sequence of the chemerin gene (GenBank: NC_007302), one pair of primers for complete exon 2 was designed with primer 5.0: forward, 5'-CAGGAGACGGAGGTGAAGC-3'; reverse, 5'-CACCGTGTCTGCCGCATT-3'.

This pair of primers was used to amplify a PCR product of about $196 \mathrm{bp}$ for the chemerin gene. Each PCR was performed in a $25-\mu \mathrm{L}$ reaction volume containing $50 \mathrm{ng}$ genomic DNA, $0.5 \mu \mathrm{L}$ of each primer $\left(10 \mathrm{mM}\right.$ ), $1 \mathrm{X}$ buffer (including $1.5 \mathrm{mM} \mathrm{MgCl}_{2}$ ), $50 \mu \mathrm{M}$ of each dNTP and $0.625 \mathrm{U}$ Taq DNA polymerase (MBI). The cycling protocol was $5 \mathrm{~min}$ at $95^{\circ} \mathrm{C}, 32$ cycles of $94^{\circ} \mathrm{C}$ for $30 \mathrm{~s}, 58.3^{\circ} \mathrm{C}$ annealing for $30 \mathrm{~s}$, and $72^{\circ} \mathrm{C}$ for $35 \mathrm{~s}$, and a final extension at $72^{\circ} \mathrm{C}$ for $10 \mathrm{~min}$. PCR products were electrophoresed on $1.5 \%$ agarose gels using $1 X$ TBE buffer ( $89 \mathrm{mM}$ Tris, $89 \mathrm{mM}$ boric acid, $2 \mathrm{mM} \mathrm{Na}_{2}$ EDTA), containing $200 \mathrm{ng} / \mathrm{mL}$ ethidium bromide.

\section{SSCP polymorphism and sequencing}

Aliquots of $6 \mu \mathrm{L}$ of the PCR products were mixed with $10 \mu \mathrm{L}$ denaturing solution (95\% formamide, $25 \mathrm{mM}$ EDTA, $0.025 \%$ xylene-cyanole, and $0.025 \%$ bromophenol blue), heated for $10 \mathrm{~min}$ at $98^{\circ} \mathrm{C}$ and chilled on ice. Next, $16 \mu \mathrm{L}$ of this mixture was applied to a $12 \%$ polyacrylamide gel (29:1 acrylamide:bis), 14\% (v/v) glycerol, and 10X TBE buffer; electrophoresis was carried out with $1 \mathrm{X}$ TBE buffer ( $89 \mathrm{mM}$ Tris-borate, $2 \mathrm{mM}$ EDTA, pH $8.3)$ at $250 \mathrm{~V}$ for $30 \mathrm{~min}$ and $115 \mathrm{~V}$ for $14 \mathrm{~h}$ at room temperature. The gel was stained with $0.1 \%$ silver nitrate (Lan et al., 2007) and visualized with $2 \% \mathrm{NaOH}$ solution (containing $0.1 \%$ formaldehyde) according to Zhang et al. (2007). After the polymorphism was detected, the PCR products of different electrophoresis patterns were sequenced in both directions in an ABI PRIZM 377 DNA sequencer. The sequences were analyzed by DNASTAR 5.0 package.

\section{Statistical analysis}

In the six cattle breeds studied, genotypic frequencies and allelic frequencies of the chemerin locus were directly calculated, Hardy-Weinberg equilibrium and differences in genotypic frequencies were analyzed using the $\chi^{2}$ test, which was performed with the SPSS soft- 
ware (version 17.0). Population genetic indices: $H_{\mathrm{E}}$ (gene heterozygosity), $H_{\mathrm{O}}$ (gene homozygosity), $N_{\mathrm{E}}$ (effective allele numbers), and PIC (polymorphism information content) were calculated according to Nei and Roychoudhury (1974) and Nei and Li (1979).

The SPSS software (version 17.0) was used to analyze the relationship between the genotypes and records of LEA, TD, BFT, WHC, and MS of Qinchuan cattle. The following linear model was used in the analysis:

$$
\mathrm{Y}_{\mathrm{ijk}}=\mu+\mathrm{A}_{\mathrm{i}}+\mathrm{G}_{\mathrm{j}}+\mathrm{S}_{\mathrm{k}}+\mathrm{E}_{\mathrm{ijk}}
$$

(Equation 1)

where $Y_{i j k}$ is the observation for the carcass measurement trait, $\mu$ is the overall population mean, $A_{i}$ is the fixed effect of the $\mathrm{i}^{\text {th }}$ age, $G_{j}$ is the fixed effect of the $\mathrm{j}^{\text {th }}$ genotype (AA, AG and GG genotype), $S_{k}$ is the fixed effect of sex, and $E_{i j k}$ is the random error.

\section{RESULTS}

\section{Genetic polymorphism of the Bos taurus chemerin gene and $\chi^{2}$ test}

Using the PCR-SSCP method, 196-bp products of the chemerin gene were amplified, which was the expected product from exon 2 of the chemerin gene. Three unique SSCP patterns for AA, AG and GG were exhibited in six cattle breeds (Figure 1). To better understand the detailed genetic variations of the chemerin gene, the three polymorphic SSCP patterns were sequenced (Figure 2). Meanwhile, the allele frequencies of the SNP were investigated and evaluated by the $\chi^{2}$ test in the six cattle breeds in our study (Table 1), which varied from 0.3841 to 0.5494 . The $\chi^{2}$ test showed that the genotype distributions in all six breeds were in HardyWeinberg equilibrium $(\mathrm{P}>0.05)$. AG was the dominant genotype in all populations studied (ranging from 0.34 to 0.59), while the frequency of the AA genotype in the total population was low in the six cattle breeds. This observation may result from the occurrence of random genetic drift due to the low frequency of allele A, except for the NY cattle and SL cattle, which was made possible by the low content of the candidate. The $N_{\mathrm{E}}$ and PIC were $1.9150,1.8979$, $1.9807,1.9728,1.9993,1.9344$ and $0.3640,0.3612,0.3725,0.3715,0.3749,0.3719$ in JRC, LX, NY, QC, SL, and XN, respectively (Table 2). According to the classification of PIC (low polymorphism $=$ PIC value $<0.25$; medium polymorphism $=0.25<$ PIC value $<0.5$, and high polymorphism $=$ PIC value $>0.5$ ), all six cattle breeds showed a medium polymorphism level.

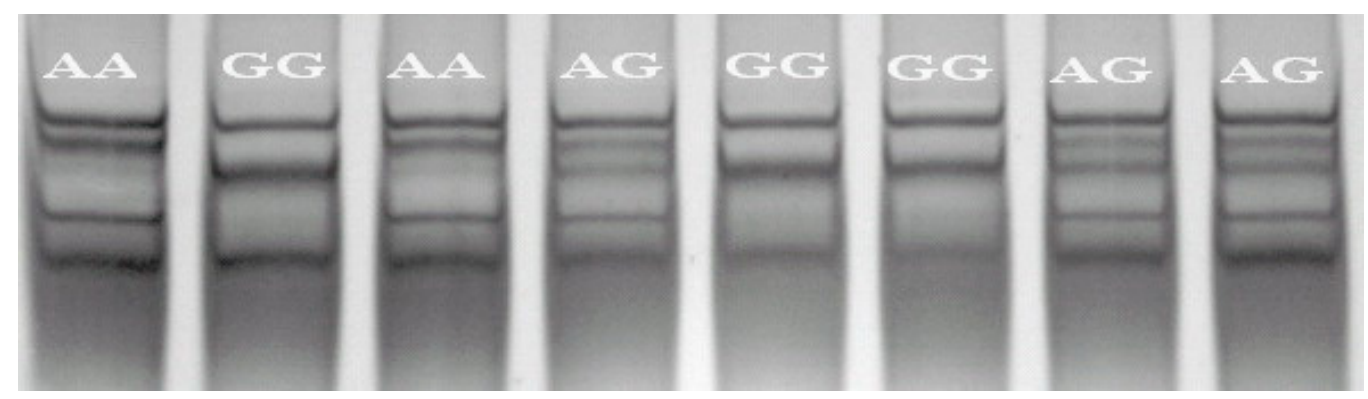

Figure 1. The electrophoresis patterns of PCR-SSCP exon 2 of the bovine chemerin gene. 


\section{A}

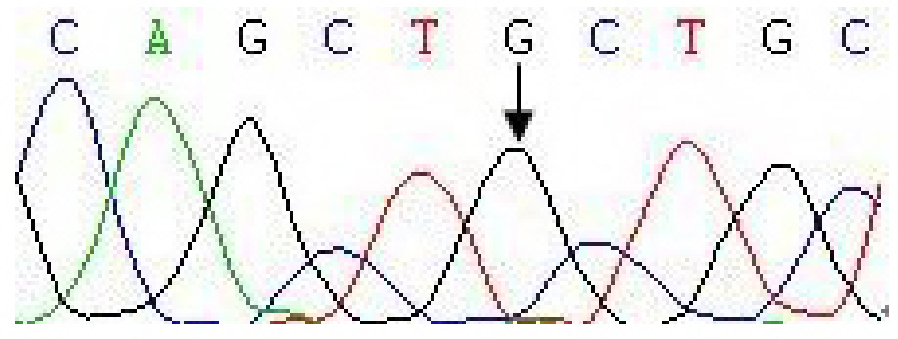

\section{$\mathrm{B}$}
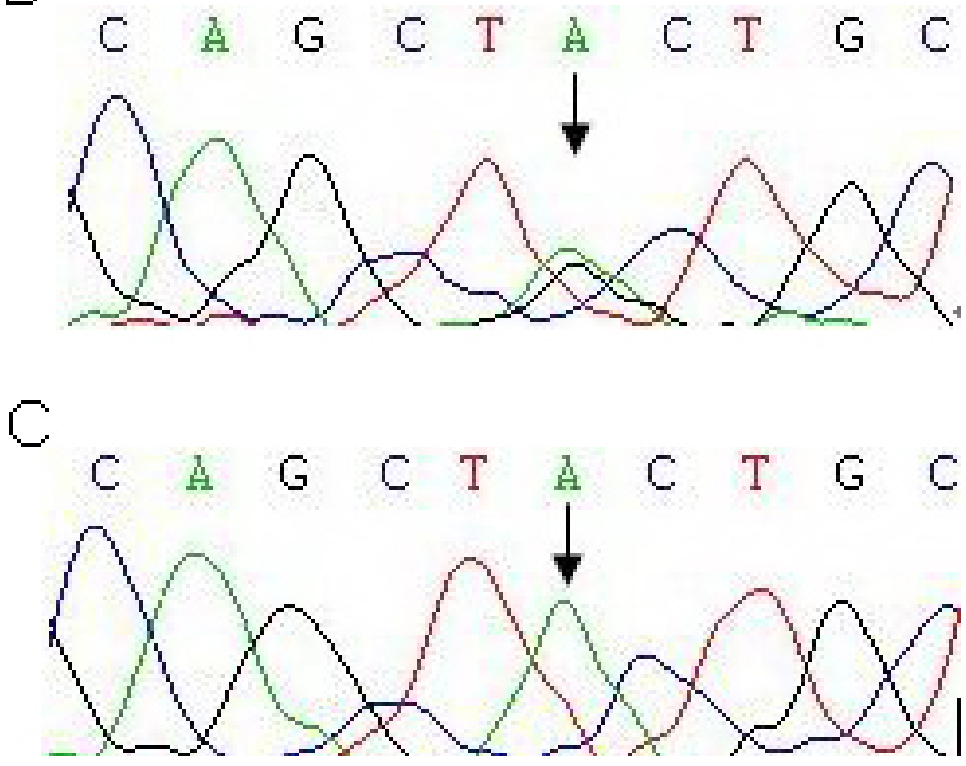

Figure 2. The sequencing traces of the novel SNP for exon 2 of the chemerin gene. Sample chromatograms of heterozygous (AG) and homozygous (AA and $\mathrm{AG}$ ) genotypes are shown. The arrow denotes the location of the polymorphism.

Table 1. Genotype frequencies (\%) at the chemerin gene for the SNP in Bos taurus populations.

\begin{tabular}{|c|c|c|c|c|c|c|c|c|}
\hline \multirow[t]{2}{*}{ Breed } & \multicolumn{3}{|c|}{ Observed genotypes (number) } & \multirow[t]{2}{*}{ Total } & \multicolumn{2}{|c|}{ Allelic frequencies } & \multirow[t]{2}{*}{$\chi^{2}(\mathrm{HW})$} & \multirow[t]{2}{*}{$\mathrm{P}$ value $(\mathrm{HW})$} \\
\hline & AA & AG & GG & & A & G & & \\
\hline JRC & $0.1690(12)$ & $0.4507(32)$ & $0.3814(27)$ & 71 & 0.3944 & 0.6056 & 0.2270 & 0.8927 \\
\hline LX & $0.0870(6)$ & $0.5942(41)$ & $0.3188(22)$ & 69 & 0.3841 & 0.6159 & 4.5198 & 0.1044 \\
\hline NY & $0.3333(27)$ & $0.4321(35)$ & $0.2346(19)$ & 81 & 0.5494 & 0.4506 & 1.3124 & 0.5188 \\
\hline QC & $0.2022(74)$ & $0.4781(175)$ & $0.3197(117)$ & 366 & 0.4413 & 0.5587 & 0.3367 & 0.8451 \\
\hline SL & $0.3396(18)$ & $0.3396(18)$ & $0.3208(17)$ & 53 & 0.5094 & 0.4906 & 5.4446 & 0.0657 \\
\hline $\mathrm{XN}$ & $0.1579(12)$ & $0.5000(38)$ & $0.3421(26)$ & 76 & 0.4079 & 0.5921 & 0.0938 & 0.9542 \\
\hline Total & $0.2081(149)$ & 0.4735 (339) & $0.3184(228)$ & 716 & 0.4448 & 0.5552 & 1.2274 & 0.5413 \\
\hline
\end{tabular}

HW = Hardy-Weinberg equilibrium; JRC = Jiaxian red; LX = Luxi; NY = Nan yang; QC = Qinchuan; SL = Simmental and Luxi crossbred steers, and XN = Xia'nan. 
Table 2. Population genetic indices at the chemerin gene locus in Bos taurus populations.

\begin{tabular}{lcccc}
\hline Breed & Gene homozygosity & Gene heterozygosity & Effective allele numbers & PIC \\
\hline JRC & 0.5220 & 0.4780 & 1.9150 & 0.3640 \\
LX & 0.5269 & 0.4731 & 1.8979 & 0.3612 \\
NY & 0.5069 & 0.4931 & 1.9807 & 0.3725 \\
QC & 0.5069 & 0.4931 & 1.9728 & 0.3715 \\
SL & 0.5002 & 0.4998 & 1.9993 & 0.3749 \\
XN & 0.5170 & 0.4830 & 1.9344 & 0.3664 \\
Total & 0.5061 & 0.4939 & 1.9759 & 0.3719 \\
\hline
\end{tabular}

PIC = polymorphism information content. For breed abbreviations, see legend to Table 1.

After a 196-bp product of the bovine chemerin gene was amplified and sequenced, we found an SNP in exon 2, named A868G in the chemerin gene, and it is a synonymous mutation of leucine, located in the fourth locus of the open reading frame (ORF).

\section{Effect of the polymorphism locus on carcass traits}

Five carcass traits (LEA, TD, BFT, WHC, and MS) were analyzed by the comparison of the genotypes of 76 individuals of Qinchuan cattle and their phenotypic data. The results of association analysis are shown in Table 3 . They showed that animals with the AG genotype have significantly lower mean values for LEA and TD compared to AA and GG genotypes ( $P$ $<0.05)$. However, there was no significant association between any individual haplotype and BFT, WHC and MS in individuals $(\mathrm{P}>0.05)$. Moreover, the $\mathrm{A}>\mathrm{G}$ synonymous mutation of leucine results in an increase in the part of the phenotypic variation, especially on the LEA and TD phenotypes in the animals studied. Therefore, we believe that the mutation for A868G could influence carcass traits; it could be a candidate molecular marker for quality improvement in Qinchuan cattle.

\begin{tabular}{|c|c|c|c|c|c|}
\hline \multirow[t]{2}{*}{ Genotype } & \multicolumn{5}{|c|}{ Traits } \\
\hline & Backfat thickness $(\mathrm{cm})$ & Loin eye area $/ \mathrm{cm}^{2}$ & Marbling score/1-5 & Water holding capability/\% & Meat tenderness $/ \mathrm{kg}$ \\
\hline $\mathrm{AA}$ & $0.813 \pm 0.138$ & $87.878 \pm 0.984^{a}$ & $1.721 \pm 0.146$ & $0.236 \pm 0.092$ & $2.183 \pm 0.470^{\mathrm{a}}$ \\
\hline $\mathrm{AG}$ & $0.976 \pm 0.064$ & $81.335 \pm 1.101^{\mathrm{b}}$ & $1.735 \pm 0.089$ & $0.228 \pm 0.016$ & $1.943 \pm 0.157^{\mathrm{b}}$ \\
\hline GG & $0.996 \pm 0.164$ & $89.443 \pm 1.223^{\mathrm{a}}$ & $1.679 \pm 0.097$ & $0.262 \pm 0.068$ & $2.146 \pm 0.253^{\mathrm{a}}$ \\
\hline
\end{tabular}

Data are reported as means \pm SE. ${ }^{\mathrm{a}, \mathrm{b}}$ Means with different superscript letters were significant at $\mathrm{P}<0.05$.

\section{DISCUSSION}

Many studies regarding adipogenesis and adipocyte metabolism, obesity and diabetes (Sell and Eckel, 2009) in humans and mice have been conducted, and some authors have reported that chemerin is a novel adipokine that regulates adipocyte differentiation and function, and is related to the pathogenesis of metabolic syndrome and that chemerin stimulates ERK1/2 and lipolysis in the 3T3-L1 adipocytes (Roh et al., 2007). A recent study showed that chemerin gene SNP rs10278590 is associated with increased visceral fat mass in nonobese subjects. In generalized obesity, this genetic effect may be masked by the close association 
between whole-body obesity and visceral fat mass (Mussig et al., 2009). We supposed that the chemerin gene is connected with the content of fat in muscle and correlated with the carcass traits such as LEA, TD, BFT, WHC, and MS in Qinchuan cattle. However, no further research was carried out on the relationship of the chemerin gene with carcass traits in animals, so we studied the SNP of this gene in cattle and determined its relevance.

A synonymous mutation of leucine was detected in exon 2 of the cattle chemerin gene, with the protein structure of chemerin unchanged, so the biological function of chemerin was not changed. However, the mutation lies in the beginning of the ORF, so it may influence the mechanism of translation, thereby affecting the expression of Chemerin, but this was not examined. Therefore, further research on this aspect is needed.

Our data indicate that the mutation possibly influenced some carcass traits of Qinchuan cattle in this study. The impact of SNPs on carcass trait variability represents a vast area for further research.

\section{ACKNOWLEDGMENTS}

Research supported by the China National 863 Program (\#2010AA10Z101, \#2008AA101010 and \#2006AA10Z1A1), the National Eleventh "Five Year" Science and Technology Support Project (\#2006BAD01A10-3), and GMO New Varieties Major Project (\#2008ZX08007-002). Moreover, the cattle populations were supported by Qinchuan Beef Cattle Breeding Center of Shaanxi Province, Nanyang, Jiaxian and Xia'nan Cattle Breeding Center of Henan Province, and Luxi Cattle Breeding Center of Shandong Province (P.R. China).

\section{REFERENCES}

Bozaoglu K, Bolton K, McMillan J, Zimmet P, et al. (2007). Chemerin is a novel adipokine associated with obesity and metabolic syndrome. Endocrinology 148: 4687-4694.

Gantz I, Konda Y, Yang YK, Miller DE, et al. (1996). Molecular cloning of a novel receptor (CMKLR1) with homology to the chemotactic factor receptors. Cytogenet. Cell Genet. 74: 286-290.

Goralski KB, McCarthy TC, Hanniman EA, Zabel BA, et al. (2007). Chemerin, a novel adipokine that regulates adipogenesis and adipocyte metabolism. J. Biol. Chem. 282: 28175-28188.

Lan XY, Pan CY, Chen H, Zhang CL, et al. (2007). An AluI PCR-RFLP detecting a silent allele at the goat POU1F1 locus and its association with production traits. Small Ruminant Res. 73: 8-12.

Martensson UE, Fenyo EM, Olde B and Owman C (2006). Characterization of the human chemerin receptor - ChemR23/ CMKLR1 - as co-receptor for human and simian immunodeficiency virus infection, and identification of virusbinding receptor domains. Virology 355: 6-17.

Meder W, Wendland M, Busmann A, Kutzleb C, et al. (2003). Characterization of human circulating TIG2 as a ligand for the orphan receptor ChemR23. FEBS Lett. 555: 495-499.

Methner A, Hermey G, Schinke B and Hermans-Borgmeyer I (1997). A novel G protein-coupled receptor with homology to neuropeptide and chemoattractant receptors expressed during bone development. Biochem. Biophys. Res. Commun. 233: 336-342.

Mullenbach R, Lagoda PJ and Welter C (1989). An efficient salt-chloroform extraction of DNA from blood and tissues. Trends Genet. 5: 391.

Mussig K, Staiger H, Machicao F, Thamer C, et al. (2009). RARRES2, encoding the novel adipokine chemerin, is a genetic determinant of disproportionate regional body fat distribution: a comparative magnetic resonance imaging study. Metabolism 58: 519-524.

Nagpal S, Patel S, Jacobe H, DiSepio D, et al. (1997). Tazarotene-induced gene 2 (TIG2), a novel retinoid-responsive gene in skin. J. Invest. Dermatol. 109: 91-95.

Nei M and Roychoudhury AK (1974). Sampling variances of heterozygosity and genetic distance. Genetics 76: 379-390. Nei M and Li WH (1979). Mathematical model for studying genetic variation in terms of restriction endonucleases. Proc. 
Natl. Acad. Sci. U. S. A. 76: 5269-5273.

Owman C, Nilsson C and Lolait SJ (1996). Cloning of cDNA encoding a putative chemoattractant receptor. Genomics 37: 187-194.

Roh SG, Song SH, Choi KC, Katoh K, et al. (2007). Chemerin - a new adipokine that modulates adipogenesis via its own receptor. Biochem. Biophys. Res. Commun. 362: 1013-1018.

Samson M, Edinger AL, Stordeur P, Rucker J, et al. (1998). ChemR23, a putative chemoattractant receptor, is expressed in monocyte-derived dendritic cells and macrophages and is a coreceptor for SIV and some primary HIV-1 strains. Eur. J. Immunol. 28: 1689-1700.

Sell $\mathrm{H}$ and Eckel J (2009). Chemotactic cytokines, obesity and type 2 diabetes: in vivo and in vitro evidence for a possible causal correlation? Proc. Nutr. Soc. 68: 378-384.

Song SH, Fukui K, Nakajima K, Kozakai T, et al. (2010). Cloning, expression analysis, and regulatory mechanisms of bovine chemerin and chemerin receptor. Domest. Anim. Endocrinol. 39: 97-105.

Takahashi M, Takahashi Y, Takahashi K, Zolotaryov FN, et al. (2008). Chemerin enhances insulin signaling and potentiates insulin-stimulated glucose uptake in 3T3-L1 adipocytes. FEBS Lett. 582: 573-578.

Wittamer V, Franssen JD, Vulcano M, Mirjolet JF, et al. (2003). Specific recruitment of antigen-presenting cells by chemerin, a novel processed ligand from human inflammatory fluids. J. Exp. Med. 198: 977-985.

Wittamer V, Bondue B, Guillabert A, Vassart G, et al. (2005). Neutrophil-mediated maturation of chemerin: a link between innate and adaptive immunity. J. Immunol. 175: 487-493.

Zabel BA, Allen SJ, Kulig P, Allen JA, et al. (2005). Chemerin activation by serine proteases of the coagulation, fibrinolytic, and inflammatory cascades. J. Biol. Chem. 280: 34661-34666.

Zhang C, Wang Y, Chen H, Lan X, et al. (2007). Enhance the efficiency of single-strand conformation polymorphism analysis by short polyacrylamide gel and modified silver staining. Anal. Biochem. 365: 286-287. 